ESTUDOS LITERÁRIOS 


\title{
DE SABIÁS E EXÍLIOS: DO BRASIL
}

\author{
Édison José da Costa*
}

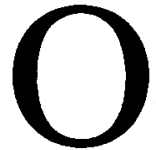

tema do exílio e os motivos a ele associados por Gonçalves Dias no célebre poema publicado em 1846, em Primeiros cantos, têm sido com freqüência retomados por poetas de sucessivas gerações. Veja-se "Uma Canção", de Mário Quintana, publicado em 1966, em Antologia poética:

\section{Uma Canção}

Minha terra não tem palmeiras...

E em vez de um mero sabià,

Cantam aves invisiveis

Nas palmeiras que não há.

Minha terra tem relógios.

Cada qual com a sua hora

Nos mais diversos instantes...

Mas onde o instante de agora?

Mas onde a palavra "onde"?

Terra ingrata, ingrato filho,

Sob os céus de minha terra

Eu canto a Canção do Exilio!

\footnotetext{
" Universidade Federal do Paraná
} 
O primeiro verso acolhe a sequiência inicial da "Canção do Exílio", alterando-a entretanto semântica e ritmicamente com a inclusão do advérbio de negação. $O$ desenvolvimento do texto assenta-se, da mesma forma, $\mathrm{em}$ sugestōes recolhidas do poema romântico: o motivo sabiá no enunciado contrastante do segundo verso; esquema de rimas limitado aos versos pares; rima oxitona puramente vocálica aproximando o trissilabo "sabiá" e o monossilabo "há"; o heptassilabo, evitado apenas, funcionalmente, no primeiro verso. O próprio título do poema, uma locução nominal, compōese, ao identificar categorialmente o trabalho poético, paralelamente ao texto do poema romântico; a presença do indefinido assinala, aliás, um despojamento que é homenagem e revisão. Percebe-se que a "Canção do Exílio" ressoa por todo o decorrer do texto de Quintana e desse modo faz-se concreto, efetiva-se, no ato mesmo em que o poema se processa, o movimento enunciado nos dois versos finais:

Sob os céus da minha terra

Eu canto a Canção do Exilio:

O poema de Quintana não apenas diz, mas é o que enuncia, não apenas se refere ao poema de Gonçalves Dias mas $e$ esse poema, porque o traz, concreto, em si.

"Uma Canção" compõe sua significaçāo estabelecendo uma relação com outro texto. Sublinha direçōes, desta forma, estabelece um roteiro para a leitura. A compreensão do poema exige, então, que também se considere a "Canção do Exilio". Nessa relação especular, todavia, o tex to segundo não apenas procura o texto primeiro para nele se mirar, como se oferece, abre-se para que nele também o texto primeiro venha se refletir. Iluminam-se mutuamente, mostram-se um ao outro à medida que dialogam entre si.

A desmontagem do poema de Gonçalves Dias efetivada em "Uma Cançāo", conforme destacado mais acima, marca a decifração do ufanismo idilico que impregna aquele texto. Apreendendo a realidade circundante em termos de negaçāo e ausência, uma vez que "aves invisiveis" cantam "nas palmeiras que não há", o eu poético esboça, no poema de Quintana, um quadro de problematização e desnorteamento incompativel com os traços de coesão e linearidade presentes no contexto evocado na "Canção do Exilio". O tempo histórico, assim formulado, desvela, no contraste estabelecido, o território do mito sobre o qual se constitui o enunciado romântico.

Na segunda estrofe, a contemporaneidade impõe-se claramente com 
o acolhimento da dimensão temporal. Revela-se a fragmentação, a perda da unidade, o descentramento:

Minha terra tem relógios,

Cada qual com a sua hora

A evocação romântica do espaço idílico dá a vez, no poema de Quintana, à expectativa de realização existencial:

Mas onde o instante de agora?

Dá a vez, extensivamente, à procura da identidade. A entonação ascendente do enunciado interrogativo, nesse verso, intensifica dramaticamente a formulação do estado de deslocamento e inquietação, e, concretizada uma segunda vez no início da última estrofe:

\section{Mas onde a palavra "onde"?}

assinala, no momento em que a linguagem se volta dilacerante sobre si própria, o curso de seu autoquestionamento. Decorrentemente, insanáveis a ruptura e a fragmentação, o fechamento do poema recompõe a forma cristalizada através da enunciação de seu título:

Sob os céus de minha terra

Eu canto a Canção do Exílio!

conjugando lá e cá em um mesmo espaço conflituoso que rejeita e é rejeitado, selando, com a reafirmação do texto inaugural, o destino trágico da nacionalidade: desafio e desalento, resistência e entrega. Desamparo.

"Sabiá", de Chico Buarque, apresentado pela primeira vez em 1968, com musica de Tom Jobim, é outro poema em cujos versos cintilam ecos da "Canção do Exílio":

\section{Sabiá}

Vou voltar

Sei que ainda vou voltar

Para o meu lugar

Foi lá e é ainda lá 


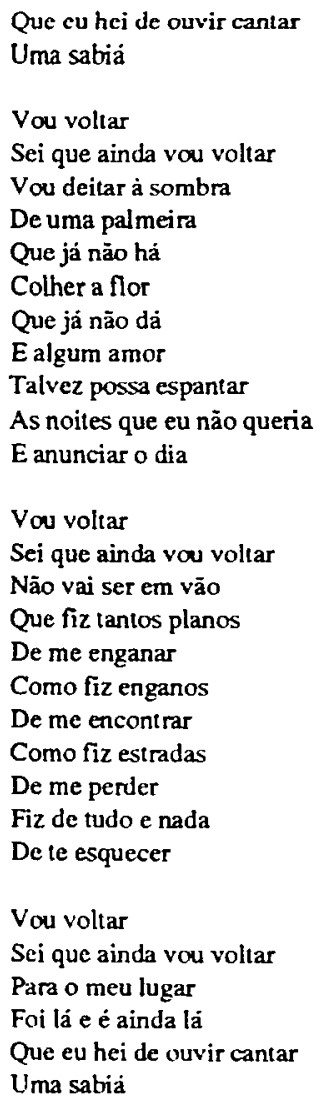

O motivo sabia, com o qual o poema estabelece, já desde seu título, balizamento para a lcitura, habita as regiōes especialmente iluminadas $\mathrm{em}$ que se constituem os símbolos, aceitos que tem sido como representação legitima da nacionalidade. A magia arquetipal de que parace impregnada a "Canção do Exílio", garantindo-lhe ressonância e permanència, é certamente fator decisivo para a efetivaçāo desse processo. O poema de Chico Buarque impregna-se dos valores associados ao motivo sabiá, acolhe a voz uterina por ele despertada e a faz soar.

"Sabiá" contrapōe dois espaços: aquele em que se encontra o poeta e o espaço para o qual deseja retornar. O primeiro, espaço das "noites que cu nāo queria", é espaço de sufocamento, de horizontes fechados. Está 
associado ao desassossego e ao desencontro que vêm constringir a linguagem da segunda estrofe, impregnada de tomeios verbais que se atropelam no adelgaçamento dos versos polissilábicos. Observe-se os seguintes versos:

\author{
Que fiz tantos planos \\ De me enganar \\ Como fiz enganos \\ De me encontrar \\ Como fiz estradas \\ De me perder \\ Fiz de tudo e nada \\ De te esquecer
}

Ao mesmo tempo em que, pela rima, "enganar" e "encontrar" se aproximam, opōem-se semanticamente; se, por outro lado, "encontrar" e "perder" se mostram semanticamente antitéticos, equivalem-se pelo preenchimento de idêntica posição sintagmática; as formas nominal e verbal - "enganos" e "enganar", respectivamente - , colocadas em posições similares - final de verso - e contíguas - versos que se sucedem imediatamente -, atraem-se fônica e semanticamente, ameaçando apagar a distinção lexical e sintática; as duas formas antitéticas do penúltimo verso identificamse posicionalmente enquanto se vê o verso como unidade, mas distinguem-se rapidamente ao se reconhecer o conjunto sintático formado pelo dístico final; ao mesmo tempo que os sintagmas adjuntivos em "enganos de me encontrar" $\mathrm{e}$ "estradas de me perder" têm sugerida uma natural familiaridade com os termos nucleares dos quais dependem, abrigam sentidos que colidem antiteticamente com o significado dos mesmos. A insistência, enfim, em uma mesma estrutura frasal básica centrada na forma pretérita do verbo fazer imprime à seqüência estrófica um movimento espiralado, um ir-e-vir que, alterando-se a cada vez apenas a tonalidade de um sentido já expresso e não a sua esséncia, torna sempre sobre os mesmos passos, irresolvido, sublinhando, no crescendo que o final da estrofe arremata, a ansiedade e a opressão como marcas do aqui e do agora em que se contorce o poeta. Há um shbor maneirista, inequivocamente, em todos esses torneios verbais e através dele, contrastando com o bucolismo evocado na estrofe anterior, desvelam-se a tensão e o conflito.

A primeira estrofe do poema desenvolve a expectativa de transcendência da situação opressiva. A recortência ao mito: 
Vou deitar à sombra

De uma palmeira

Que já não há

expõe o esforço de atualização de valores perdidos:

Colher a flor

Que já não dá

conjugados espaço edênico original e movimento de retorno. Retorno que não é retirada ou derrota, mas procura de inspiração; retorno que tem em vista o futuro:

\author{
E algum amor \\ Talvez possa espantar \\ As noites que eu não queria \\ E anunciar o dia
}

Retorno, portanto, às fontes mesmas da vida, para fortalecimento. Dessa forma, o canto do sabiá, anunciado no estribilho:

Que eu hei de ouvir cantar

Uma sabiá

é a voz que nasce das profundezas da alma nacional exigindo disposição e sensibilidade: "Eu hei de ouvir", eternizando o ideal de liberdade, o sonho de fraternidade, a sede de felicidade. Guja e inspiração.

Ecos da "Canção do Exilio" deixam-se ouvir também em poemas de outros escritores. Levantamento rápido permite apontar Casimiro de Abreu, Oswald de Andrade, Murilo Mendes, Carlos Drummond de Andrade, Ribeiro Couto e José Paulo Paes. Referências constante, geração após geração, o texto do poeta romântico vai se estabelecendo como forma fundadora no repertório de textos nacionais. Composta em momento crucial para a afinnação da nacionalidade, poucos anos após a proclamação da independência, a "Canção do Exilio" conjuga a exaltação do espaço natal c o lamento por estar ausente dele. Pode estar aí um dos segredos para a compreensão da permanéncia do poema, nesse coexistir de realização e frustração, nessa dualidade em que costumam se debater as histórias in- 
dividuais e na qual se debate ininterruptamente a história nacional. Considere-se, muito a propósito, que "Sabiá" foi apresentada ao público do Festival Internacional da Canção, no Rio de Janeiro, exatamente no ano de 1968, às vésperas da decretação do Ato Institucional n 5; que sepultava de vez o esforço de afirmação nacional e popular pelo golpe militar de 1964. Texto inaugural, a "Canção do Exílio" codifica uma visão de mundo e deflagra experiências. Assentados culturalmente como elementos de interpretação e conhecimento, motivos com os quais o poema de Gonçalves Dias trabalha, assim como a focalização que imprime ao tema do exílio, vêm à tona, renovados, em diferentes momentos da criação literária no Brasil. Testemunham o desencanto e o aturdimento: o recorrente exilio do homem nacional.

\section{RESUMO}

Análise dos poemas "Uma Canção", de Mário Quintana, e "Sabia", de Chico Buarque. Focaliza-se principalmente a relação que ambos estabelecem com a "Canção do Exilio", de Gonçalves Dias.

\section{REFERENCIAS BIBLIOGRÁFICAS}

DIAS, Antônjo Gonçalves. Poemas de Gonçalves Dias. São Paulo: Cultrix, 1968.

HOLlandA. Chico Buarque de. Chico Buarque, letra e mísica. São Paulo: Companhia das Letras, 1989.

QUINTANA, Mário: Antologia poética. Rio de Janeiro: Editora do Autor, 1966. 